\title{
Oral and maxillofacial injuries in preschool children: a study in a hospital in southern Brazil
}

\section{Lesões orais e maxilofaciais em crianças pré-escolares: estudo em um hospital do sul do Brasil}

\author{
Paulo Floriani Kramer \\ Lise Andrea Becker Dietrich ${ }^{* * *}$ \\ Moises Zacarias Cardoso ${ }^{* * *}$ \\ Tássia Silvana Borges ${ }^{* *}$ \\ Milene Castilhos de Oliveira* \\ Sergio Augusto Quevedo Miguens Jr*
}

\begin{abstract}
Objective: Oral and maxillofacial (OMF) injuries in children may lead to developmental and functional disorders. In this cross-sectional study, we analyzed the pattern of OMF injuries in preschool children admitted to the emergency department of a hospital in southern Brazil. Subjects and method: We retrospectively reviewed the medical records of 1,533 patients admitted from January to December 2011 to identify children aged 0 to 5 years with a diagnosis of OMF trauma. Data were collected on demographic, seasonal and clinical variables. Results: The sample consisted of 288 preschool children (aged 0-5 years) with OMF injuries. Of these, $61.1 \%$ were male and $53.2 \%$ were $<3$ years of age. Most children (84.8\%) received first medical care from an dentist. Isolated facial injuries were the most common type of injury (85.1\%) in this age group. Soft tissue injuries were the most common injury outcome (77.9\%), occurring mainly in the nose and lips. Random accidents were the most common cause of OMF trauma $(87.7 \%)$, and injuries due to falls occurred in $85.9 \%$ of these cases. The most common dental trauma was tooth displacement (69.6\%). Conclusion: In conclusion, our findings indicate a higher prevalence of OMF injuries in soft tissues, especially in boys in the first three years of life. Falls were the leading cause of injury. Information related to OMF injuries in children are essential for the control of accidents and development of public health policies.
\end{abstract}

Keywords: Facial injuries; emergency medical services; descriptive epidemiology.

\section{Introduction}

Facial injuries due to accidents or interpersonal violence are a serious public health problem in early childhood ${ }^{1}$. After the first year of life, facial trauma is the leading cause of hospitalization and death $^{2}$. The prevalence of oral and maxillofacial (OMF) injuries in preschool children ranges from 8.9 to $48.1 \%^{3-10}$. Also, an important consideration is the vulnerability of this age group to accidental trauma, as even minor injuries may lead to developmental, functional and psychological disorders ${ }^{9,11}$.

Home falls and accidents are the most common cause of OMF injuries in children, while motor vehicle accidents, sports and interpersonal violence account for most injuries in older individuals ${ }^{10}$. Environmental, cultural and social factors, however, contribute to the incidence, etiology and site of injury ${ }^{12,13}$. Traumatic dental injuries and soft tissue injuries are the most common type of injury in children and adolescents ${ }^{4,10,14}$. Anatomical features such as increased bone elasticity, decreased thickness of the soft tissue covering the facial skeleton and lack of development and pneumatization of the paranasal sinuses contribute to reducing the frequency of facial fractures in this age group ${ }^{4,15}$.

Epidemiological studies are essential for the development of emergency protocols and implementation of public policies to prevent and reduce OMF injuries and their effects. However, studies addressing facial trauma and associated factors in

\footnotetext{
PhD associate professor, Universidade Luterana do Brasil (ULBRA), Canoas, RS, Brazil.

PhD associate professor, Universidade Luterana do Brasil (ULBRA), Palmas, TO, Brazil.

Master's Degree in Dentistry, Universidade Luterana do Brasil (ULBRA), Canoas, RS, Brazil.
} 
children are scarce ${ }^{8,10,11,16}$. Therefore, the objective of the current study was to analyze the pattern of OMF injuries in preschool children admitted to the emergency department (ED) of a hospital in southern Brazil, considering demographic, seasonal and clinical variables. Also etiology, affected soft tissue injury, bone fractures, and traumatic dental injuries were investigated.

\section{Subjects and method}

\section{Study Setting}

The study was conducted in the ED of Hospital de Pronto Socorro, a hospital-based that provides emergency care to adults and children in the city of Canoas, southern Brazil. The city has a population of approximately 324,000 and primary care is provided in 24 community health centers. The hospital's ED operates 24 hours a day and triage procedures are used to prioritize the need for medical care based on risk assessment, i.e., the most severe cases are given priority. In addition, the Advanced Trauma Life Support (ATLS) protocol, developed by the American College of Surgeons, is used in the management of acute trauma cases at the hospital ${ }^{17}$.

\section{Participants and Study Design}

This was a cross-sectional study with retrospective medical record review of all patients admitted to the ED between January 1 and December 31, 2011. Eligible participants were all children aged 0 to 5 years who had a diagnosis of OMF trauma.

\section{Data Collection}

All data were extracted by a single investigator, previously trained by an experienced researcher, using a standardized data collection form for each patient. The following data were collected from the patients' medical records: demographic variables (sex and age); seasonal variables (month, day of week, and time of arrival in the ED); clinical variables (health professional who provided the first medical care in the ED, type of injury, injury outcome, and clinical outcome); etiology of injury; affected soft tissue injury, bone fractures and traumatic dental injuries.

\section{Data Analysis}

We did not exclude incomplete medical records but rather used the information provided in the analysis. To address this issue, we indicated the number of patients for each variable analyzed. Data were expressed as absolute and relative frequencies. Data analysis was performed using SPSS, version 13.0.

\section{Ethical Considerations}

The study was approved by the Research Ethics Committee of the institution (protocol number $170,173)$ and conducted in accordance with the provisions of the Declaration of Helsinki. Informed consent was waived due to the non-interventional design of the study and retrospective nature of data collection.

\section{Results}

A total of 1,533 patients were admitted to the ED from January to December 2011. Of these, $288(18.8 \%)$ were preschool children (aged 0 to 5 years) with a diagnosis of OMF trauma and were included in the analysis. Because of incomplete data recording, different patient numbers are presented for some variables.

The demographic, seasonal, and clinical features of the patients are shown in Table 1. Most patients $(61.1 \%)$ were male, and $53.2 \%$ were $<3$ years of age. ED visits occurred more frequently in the months of June (12.5\%) and July (11.8\%), during the afternoon $(37.2 \%)$ and evening/night $(42.0 \%)$, and on weekends $(38.6 \%)$. Isolated facial injuries were the most common type of injury in this age group, accounting for $85.1 \%$ of ED visits. Soft tissue injuries were the most common injury outcome, accounting for $77.9 \%$ of cases. Transfers and hospitalizations accounted for only $2.1 \%$ of clinical outcomes. Most children (84.8\%) received first medical care from an dentist. 
Table 1 - Demographic, seasonal, and clinical features of pediatric patients with oral and maxillofacial injuries admitted to the emergency department of a hospital in southern Brazil

\begin{tabular}{|c|}
\hline Demographic variables \\
\hline Sex \\
\hline Male \\
\hline Female \\
\hline Age (months) \\
\hline $0-11$ \\
\hline $12-23$ \\
\hline $24-35$ \\
\hline $36-47$ \\
\hline $48-59$ \\
\hline $60-71$ \\
\hline Seasonal variables \\
\hline Visits/Month \\
\hline January \\
\hline February \\
\hline March \\
\hline April \\
\hline May \\
\hline June \\
\hline July \\
\hline August \\
\hline September \\
\hline October \\
\hline November \\
\hline December \\
\hline Visits/Week \\
\hline Sunday \\
\hline Monday \\
\hline Tuesday \\
\hline Wednesday \\
\hline Thursday \\
\hline Friday \\
\hline Saturday \\
\hline Visits/Time \\
\hline $1-6$ a.m. (early morning) \\
\hline 7 a.m. - 12 p.m. (morning) \\
\hline 1 - 6 p.m. (afternoon) \\
\hline 7 p.m. - 12 a.m. (evening/night) \\
\hline
\end{tabular}

\section{Clinical variables}

First medical care

Dentist

Both

Physician

Type of injury

Isolated facial trauma

Facial trauma and TBI

Multiple trauma

Injury outcome

Soft tissue injuries

Associated injuries

Bone fractures

Traumatic Dental Injury

Clinical outcome

Resolutive

Transfer and/or hospitalization

$\overline{\mathrm{TBI}}=$ traumatic brain injury.

* Because of incomplete data recording, different patient numbers are presented for different variables.
$71(24.7)$

57 (19.8)

$41(14.2)$

39 (13.5)

$55(19.1)$

288

$10(3.5)$

$29(10.1)$

$24(8.3)$

$24(8.3)$

$29(10.1)$

36 (12.5)

34 (11.8)

$27(9.4)$

27 (9.4)

16 (5.6)

09 (3.1)

$23(8.0)$

288

50 (17.4)

31 (10.8)

41 (14.2)

30 (10.4)

41 (14.2)

34 (11.8)

61 (21.2)

274

$21(7.7)$

36 (13.1)

$102(37.2)$

115 (42.0)

231

123 (53.2)

73 (31.6)

35 (15.2)

288

245 (85.1)

35 (12.2)

08 (2.8)

285

222 (77.9)

$44(15.4)$

04 (1.4)

15 (5.3)

233

228 (97.9)

$05(2.1)$

Data associated with the etiology of OMF injuries are shown in Table 2. Random accidents were the most common cause of OMF trauma, accounting for 177 cases (87.7\%); of these, 152 (85.9\%) were associated with falls. Traffic accidents accounted for $10.8 \%$ of OMF injuries, most of which were bicycle-related (56.3\%). Only 2 injuries (1.5\%) were caused by interpersonal violence.

Table 2 - Etiology of oral and maxillofacial injuries in pediatric patients admitted to the emergency department of a hospital in southern Brazil

\begin{tabular}{l|r|r|}
\cline { 2 - 3 } & $\mathrm{N}(\%)$ & \multicolumn{1}{|c|}{$\mathrm{n}(\%)$} \\
\hline Random accidents & $177(87.7)$ & $152(85.9)$ \\
Falls & & $14(7.9)$ \\
Other & & $08(4.5)$ \\
Animal bite & $03(1.7)$ \\
$\quad$ Human bite & $16(10.8)$ & \\
Traffic accidents & & $09(56.3)$ \\
Bicycle & & $05(31.3)$ \\
Motor vehicle & $02(12.5)$ \\
Being run over & & \\
Interpersonal violence & & \\
Physical aggression & & $01(50.0)$ \\
Knives & & $01(50.0)$ \\
\hline
\end{tabular}

The most common sites of soft tissue injury were the nose (27.4\%) and lips (27.0\%). Nasal bone injuries accounted for $75.9 \%$ of all bone fractures. The most common dental trauma was tooth displacement $(69.6 \%)$, including luxation, intrusion and extrusion, followed by avulsion (13.0\%), associated tooth injuries $(8.7 \%)$, crown fracture $(6.5 \%)$, and dentoalveolar fractures $(2.2 \%)$ (Table 3 ).

Table 3 - Soft tissue injuries, bone fractures and traumatic dental injury in pediatric patients admitted to the emergency department of a hospital in southern Brazil

\begin{tabular}{|c|c|c|}
\hline & $\mathrm{N}$ & $\mathrm{n}(\%)$ \\
\hline \multicolumn{3}{|l|}{ Soft tissue injuries } \\
\hline Site - region & 215 & \\
\hline Nasal & & $59(27.4)$ \\
\hline Labial & & $58(27.0)$ \\
\hline Associated injuries & & $34(15.8)$ \\
\hline Periorbital & & $18(8.4)$ \\
\hline Chin & & $18(8.4)$ \\
\hline Intraoral & & $15(7.0)$ \\
\hline Frontal & & $13(6.0)$ \\
\hline \multicolumn{3}{|l|}{ Bone fractures } \\
\hline Site - region & 54 & \\
\hline Nasal & & $41(75.9)$ \\
\hline Periorbital & & $04(7.4)$ \\
\hline Zygomatic complex & & $03(5.6)$ \\
\hline Mandibular & & $02(3.7)$ \\
\hline Alveolar & & $01(1.9)$ \\
\hline Maxillary & & $01(1.9)$ \\
\hline Frontal & & $01(1.9)$ \\
\hline Associated injuries & & $01(1.9)$ \\
\hline Traumatic dental injury & 46 & \\
\hline Tooth displacement & & $32(69.6)$ \\
\hline Avulsion & & $06(13.0)$ \\
\hline Associated injuries & & $04(8.7)$ \\
\hline Crown fracture & & $03(6.5)$ \\
\hline Dentoalveolar fractures & & $01(2.2)$ \\
\hline
\end{tabular}




\section{Discussion}

The present study showed a high prevalence of OMF injuries in preschool children admitted to the ED of a hospital in southern Brazil. Most were an isolated facial trauma due to falls in boys and main outcomes were related to soft tissue injuries. In addition, 85\% of cases of OMF injuries were resolutive and dentist attended in the most cases.

The higher frequency of OMF injuries in boys is consistent with studies in different countries and different age groups $s^{4,5,10,11,18-20}$. A possible explanation for the difference between boys and girls is that boys may be more hyperactive and more frequently participate in contact sports and outdoor activities than girls even in preschool age $\mathrm{e}^{5,11,21}$.

Most cases of OMF trauma among preschoolers occurred in the first three years of life and were mostly due to falls. In this young age group, children are learning to walk, but their motor skills are still immature. Moreover, the large size of the head relative to the body contributes to falling forward and they become more prone to facial injuries ${ }^{[5,10,11]}$. In older children and adolescents, injuries are often associated with traffic accidents, interpersonal violence, and contact sports ${ }^{4,5,10}$.

Seasonal data are rarely described in epidemiological studies and are dependent on the urban dynamics of the area of data collection. Although no significant differences were observed in seasonal variables, ED visits occurred more frequently in the afternoons and evenings, especially on weekends. Childhood is characterized by vulnerability and dependence, and the parents or caregivers hold the responsibility for safety and accident prevention; therefore, simple carelessness can cause accidents ${ }^{22}$.

Isolated facial injuries were the most common type of injury, followed by facial trauma associated with brain injury. Regarding injury outcome, soft tissue injuries were more prevalent and identified most frequently in the nose and lips, a finding consistent with observations in the literature $e^{4,5,10,11}$. The prevalence of traumatic dental injuries and bone fractures was low in the present study. When present, fractures involved more often the nasal, periorbital and zygomatic bones, while dental trauma included mostly tooth displacement and avulsion.

Gassner et al., (2004) $)^{5}$ and Rahman et al., $(2007)^{10}$ reported that soft tissue injuries and traumatic dental injury are more common in the first years of life. Yang et al., (2014) ${ }^{11}$ reported that soft tissues of the lower face are most commonly affected, especially in the lip region, due to the prominence of the mandible in the facial skeleton. Kotecha et al., $(2008)^{5}$ and Haug et al., $(2000)^{20}$ pointed out that facial fractures often involve the nasal, orbital and zygomatic bones, and that nasal fractures predominate because of the prominence of the nose and its highly cartilaginous structure in the early years of development.

The dentists in the hospital team is important to the delivery of better oral health care to patients and to the provision of comprehensive oral health care services for the population. According to Silva et al., $(2011)^{23}$, of the organization of hospital services, emergency dental services and OMF surgery should be handled in the same unit and by the same team. In the present study, in approximately $85 \%$ of OMF injury cases, children received first medical care from an dentist. It is worth highlighting the importance of the presence of dentist in the hospital setting and of policies to develop interdisciplinary team competencies aiming to improve the relationship with patients and their families ${ }^{24}$.

The limitations of this study are related to its retrospective and cross-sectional design, which precludes inferences regarding causality. Therefore, our results should be interpreted with caution. In addition, we believe that longitudinal studies should be performed and patients should be monitored for sequelae of the injury.

The impact of accidental injury or violence-related injuries is directly related to the inherent vulnerability of children during growth and development. Thus, epidemiological studies involving different age groups should be encouraged as they can contribute to the planning of public policies focused on the prevention and treatment of OMF injuries. Information generated from health systems is therefore essential for improving and updating protocols for clinical care.

\section{Conclusion}

The results of the present study indicate a high prevalence of OMF injuries in early childhood. Falls were the leading cause of injury, and the main injury outcome was soft tissue injuries in the nose and lips. The effective treatment of OMF injuries and involvement of the dentist characterized most clinical outcomes, highlighting the value of interdisciplinary actions in the context of health care.

\section{Resumo}

Objetivo: lesões orais e maxilofaciais (OMF) em crianças podem levar a inúmeros distúrbios funcionais e do desenvolvimento. Este estudo transversal analizou o padrão das lesões OMF em crianças pré-escolares atendidas no departamento de emergência de um hospital do sul do Brasil. Sujeitos e métodos: Foram analizados 1533 registros médicos dos pacientes atendidos de Janeiro a Dezembro de 2011 para selecionar crianças de 0 a 5 anos de idade com diagnóstico de lesões OMF. Resultados: A amostra é composta por 288 crianças pré-escolares (com idade variando de 0 a 5 anos) com lesões OMF. Observou-se que $61.1 \%$ eram meninos e $53.2 \%$ eram menores de 3 anos de idade. A maior 
parte das crianças $(84.8 \%)$ recebeu o primerio atendimento de um dentista. Lesões facias isoladas foram o tipo de injúria mais comum (85.1\%) nesta faixa etária. O principal desfecho clínico foi a presença de lesões de tecidos moles $(77.9 \%)$, afetando principalmente nariz e lábios. Acidentes casuais foram a principal causa de traumas OMF (87.7\%) e as injúrias ocasionadas por quedas ocorreram em $85.9 \%$ destes casos. Os traumatismos dentários mais comuns foram as luxações dentárias (69.6\%). Conclusão: Os achados indicam uma alta prevalência de lesões OMF em tecidos moles, especialmente em meninos, nos primeiros três anos de vida. A queda foi a principal causa dessas injúrias. A obtenção de informações relacionadas as lesões OMF em crianças possibilita o controle de acidentes e o desenvolvimento de políticas públicas voltadas a esse tipo de injúrias nesse estrato populacional.

Palavras-chave: lesões faciais; serviços médicos de emergência; epidemiologia descritiva.

\section{References}

1. Pfeiffer L, Rosário NA, Cat MNL. Violência contra criança e adolescente: proposta de classificação dos níveis de gravidade. Rev Paul Pediatr 2011; 29:477-482.

2. Pereira Jr GA, AndreGhetto AC, Balise-Filho A, Andrade JI. Trauma no paciente pediátrico. Med (Ribeirão Preto) 1999; 32: 262-281.

3. Bregagnolo LA, Bragagnolo JC, Silveira F, Bérgamo AL, Santi LN, Watanabe MGC. Oral and Maxillofacial Trauma in Brazilian Children and Adolescents. Braz Dent J 2013; 24: 397-401.

4. Gassner R, Tuli T, Hächl O, Moreira R, Ulmer H. Craniomaxillofacial Trauma in Children: A Review of 3,385 Cases With 6,060 Injuries in 10 Years. J Oral Maxillof Surg 2004; 62: 399-407.

5. Kotecha S, Scannell J, Monaghan A, Williams RW. A four year retrospective study of 1,062 patients presenting with maxillofacial emergencies at a specialist paediatric hospital. Br J Oral Maxillof Surg 2008; 46: 293-296.

6. Kumaraswamy SV, Madan N, Keerthi R, Singh DS. Pediatric injuries in maxillofacial trauma: a 5 year study. J Maxillofac Oral Surg, 2008; 8: 150-153.

7. Kambalimath HV, Argawal SM, Kambalimath DH, Singh M, Jain N, Michael P. Maxillofacial Injuries in Children: A 10 year Retrospective Study. J Maxillof Oral Surg 2013; 12: 140-144.

8. Osunde OD, Amole IO, Ver-OR N, Akhiwu BI, Adebola RA, Iyogun $\mathrm{CA}$, et al. Pediatric maxillofacial injuries at a $\mathrm{Ni}$ gerian teaching hospital: A three-year review. Niger J Clin Pract 2016; 16: 149-154.

9. Qing-Bin Z, Zhao-Qiang Z, Dan C, Yan Z. Epidemiology of maxillofacial injury in children under 15 years of age in southern China. Oral Maxillof Surg 2013; 115: 436-441.

10. Rahman RA, Ramli R, Rahman NA, Hussaini HM, Ai IDRUS SM, Hamid ALA. Maxillofacial trauma of pediatric patients in Malaysia: A retrospective study from 1999 to 2001 in three hospitals. Int $\mathrm{J}$ of Ped Otorhinolaryngology 2007; 71: 929-936.

11. Yang RT, Li ZB. Maxillofacial Injuries in Infants and Preschools: A 2.5-Year Study. J of Craniofacial Surg 2014; 25: 964-967.
12. Adeyemo WL, Ladeinde AL, OgunLewe MO, Janes O. Tends and caracteristics of oral and maxillofacial injuries in $\mathrm{Ni}$ géria: a review of literature. Head face Med 2005; 1: 6-9.

13. Van Den Bergh B, Karagozoglu KH, Heyman MW, Forouzanfar T. Aetiology and incidence of maxillofacial trauma in Amsterdam: A retrospective analysis of 579 patients. J Cranio-Maxillof Surg 2012; 40: 165-169.

14. Hattab NM, Lahmiti S, Bouihi ME, Hiroual A, Bouaichi A. Facial wounds: An epidemiological review of 850 cases. Rev Stomatol Chir Maxillof 2011; 112: 135-138.

15. Alcalá-Galiano A, Arribas-García IJ, Martín-Pérez MA, Ana R, Montalvo-Moreno JJ, Juncos JMM. Pediatric facial fractures: children are not just small adults. Radiographics 2008; 28: 441-446.

16. Jim Z, Jiang X, Shang L. Analysis of 627 hospitalized maxillofacial- oral injuries in Xi'an, China. Dent Traumat 2014; 30: $147-153$

17. American College of Surgeons Committee on Trauma ATLS, advanced trauma life support for doctors: student course manual. Chicago, IL: American College of Surgeon, cop. 2008-8 ${ }^{\text {th }}$ ed.

18. Al-Dajani M, Quinonez C, Macpherson AK, Clokie C, Azarpazhooh A. Epidemiology of Maxillofacial Injuries in Ontario, Canada. J Oral Maxillof Surg 2015; 73: 693-699.

19. Goulart DR, Colombo A, de Moraes M, Asprino L. What is expected from a facial trauma caused by violence? J Oral Maxillof Res 2014; 5: 1-7.

20. Haug RH, Foss J. Maxillofacial injuries in the pediatric patient. Oral Surg Oral Med Oral Pathol Oral Radiol Endod 2000; 90: 126-134.

21. Gershon J. A meta-analytic review of gender differences in ADHD. J of Att Dis 2002; 5:143-154.

22. Amaral EMS, Silva CLM, Pereira ERR, Guamieri G, Brito GSS, Oliveira LM. Incidência de acidentes com crianças em um pronto-socorro infantil. Rev Inst Ciên Saúde 2009; 27:313-7.

23. Silva CJ, Ferreira EF, Paula LP, Naves MD, Gones VE Perfil dos traumas maxilofaciais em vítimas de violência interpessoal: uma análise retrospectiva dos casos registrados em um hospital público de Belo Horizonte (MG). Cad Saúde Colet 2011; 19: 33-40.

24. Matos E, Pires DEP, Campos GWS. Work relationships among interdisciplinary teams: contributions for new methods of organization in health work. Rev Bras Enferm 2009; 62: 863-869

\section{Endereço para correspondência:}

Moisés Zacarias Cardoso

Rua B, número 107, Marau, Rio Grande do Sul,. Cep: 99150-000

Fone: 55-54-991.292.666

E-mail: moisescardosocdped@gmail.com

Recebido: 27/01/2017. Aceito: 25/02/2017. 